\title{
Eks-røykere og lårhalsbrudd
}

\author{
Lisa Forsén \\ Statens institutt for folkehelse, Seksjon for epidemiologi, Postboks 4404 Torshov, 0403 Oslo
}

\section{BAKGRUNN}

Flere studier har vist at det er en interaksjon mellom body mass index, røyking og lårhalsbrudd for kvinner (1-3). Det vil si, når tynne kvinner røyker, øker de sin risiko for lårhalsbrudd adskillig mer enn det tykkere kvinner gjør når de røyker. Denne interaksjonen er ikke funnet å gjelde for menn. Deres relative risiko av å røyke er ca. 2 uansett hvor tynne de er (Figur 1).

Figur 1 viser også effekten av fysisk inaktivitet på lårhalsbrudd hvor relativ risiko er lik 2 for menn og 1,4 for kvinner (1).

Man tror at forklaringen på kjønnsforskjellen når det gjelder røyking og lårhalsbrudd må være at røyking påvirker østrogenproduksjonen hos kvinner som igjen påvirker remodelleringen av benmasse. Tynne kvinner er sårbare overfor endringer i østrogenproduksjonen i ovariene, mens tykkere kvinner blir beskyttet av den østrogenproduksjonen som finner sted i fettvevet. Menn er ikke på samme måte avhengig av østrogen for remodelleringen av benmasse. De mannlige kjønnshormonene spiller en rolle, men produksjon av testosteron er ikke slik påvirket av body mass index.

For tynne, røykende kvinner kan risikoen for osteoporose være mangedoblet (Figur 1). Gjennomsnittlig sett har disse kvinnene et skjelett som om de skulle vært 10-15 år eldre enn de egentlig er (1). Det er ikke uten videre gitt at det hjelper å slutte å røyke. Kanskje er skaden som er skjedd uopprettelig. Vi ønsket derfor å studere reversibiliteten av den uheldige røykeeffekten på risikoen for lårhalsbrudd når røykingen plutselig opphører.

\section{METODE}

Vi har basert våre analyser (Cox regresjon) på en kohortestudie med 3 års oppfølging på lårhalsbrudd. Befolkningsdataene er innsamlet av Statens Helseundersøkelser i perioden 1984 til 1986 i NordTrøndelag. Alle i fylket som var eldre enn 20 år, ble invitert til å delta. Vi har konsentrert oss om de over 50 år, og for disse var fremmøteprosenten $90 \%$. Dataene inneholder informasjon om blant annet røykevaner. I prinsippet blir alle nordtrøndere som får lårhalsbrudd behandlet enten på Innherred sykehus eller på Namdal sykehus. Ved å gå gjennom sykehusjournalene fant vi at 524 personer fra befolkningen hadde pådratt seg et lårhalsbrudd i løpet av de første 3 årene etter at screeningen var avsluttet, det vil si i perioden fra 1986 til 1989.

Ved hjelp av 9 spørsmål om røykevaner har vi klassifisert folk i 4 forskjellige røykestatus-grupper, nemlig 1) Aldri røkt daglig, 2) Sluttet med daglig røyking for mer enn 5 år siden, 3) Sluttet med daglig røyking for høyst 5 år siden, og 4) Daglig røyker for tiden. En liten gruppe var det umulig å klassifisere - enten fordi tiden som eks-røyker var ukjent eller fordi de hadde motstridende svar. Disse har vi fjernet fra analysen. Vi har studert hvordan en rekke variable for fysisk og psykisk helse og livsstil varierte med røykestatus.
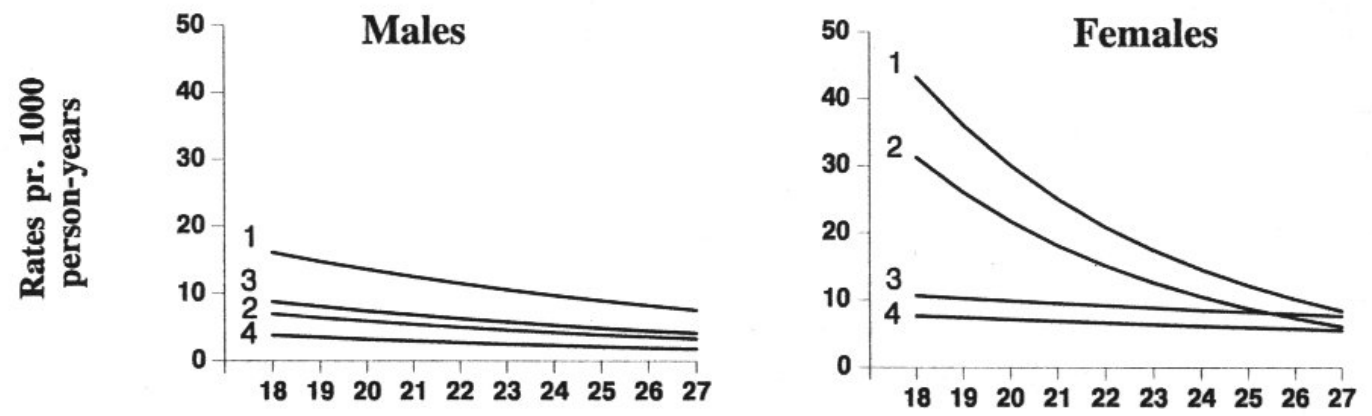

\section{Body mass index}

1 Physical inactive smokers

2 Physical active smokers
3 Physical inactive non-smokers

4 Physical active non-smokers

Figur 1 (fra Forsén et al. (1)). The model-estimated rate of hip fracture per 1000 person-years varies with body mass index $\left(\mathrm{kg} / \mathrm{m}^{2}\right)$, current smoking (yes/no) and physical inactivity (yes/no). Poisson regression is used instead of Cox regression to estimate the incidence rates. The models are based on 13994 males, of whom 89 suffered a hip fracture during the period March 1986 to March 1989, and 14598 females, of whom 220 suffered a hip fracture during the same period. The age is chosen to be 75 years, and self-reported health is chosen to be good or very good. 


\section{FORELØPIGE RESULTATER}

Gruppene som aldri hadde røkt var i gjennomsnitt eldre enn dagligrøykere og eks-røykere. Men det var mer enn gjennomsnittsalder som skilte røykere og ikke-røykere.

Gruppen som aldri hadde røkt kom helsemessig best ut på samtlige av variablene for fysisk og psykisk helse og livsstil da vi kontrollerte for alder. Resultatet var alltid statistisk signifikant, for begge kjønn både for de over og de under 65 år - ofte med p-verdier på under 0,0001. Det at røykestatusgruppene var så forskjellige på disse variablene kan like gjerne skyldes seleksjon som det at folk endrer seg etter røykeslutt. Antagelig gjelder begge deler.

Eks-røykerne hadde som regel verdier mellom gjennomsnittsverdien til aldri røkt gruppen og gjennomsnittsverdien til dagligrøykerne på disse helse- og livsstilsvariablene. Men det er ikke gitt at de hadde slike mellomliggende verdier fordi de hadde sluttet å røyke. En del greide nok å slutte nettopp fordi de hadde slike verdier i utgangspunktet.

Insidensen av lårhalsbrudd, estimert ved hjelp av en Poisson regresjonsmodell basert på alle aldersgruppene, viser en dobbelt så høy verdi for røykerne som for eks-røykerne og de som aldri hadde røkt daglig. De to sistnevnte hadde insidenser på samme nivå.

Spørsmålet er om risikoen for lårhalsbrudd var så lav for eks-røykere bare fordi eks-røykere hadde lagt på seg, var mer fysisk aktive og hadde en bedre fysisk og psykisk helse enn røykerne.

Foreløpige analyser (Cox regresjon) viser at selv ved kontroll for fysisk og psykisk helse og livsstil, hadde eks-røykerne fått redusert sitt risikonivå ned til nivået til de som aldri hadde røkt daglig.

\section{FORELØPIG KONKLUSJON}

Det ser ut til at eksrøykere får redusert sin risiko for lårhalsbrudd til et nivå som ikke er statistisk signifikant høyere enn "aldri røkt" nivå, og dette ser ut til å være uavhengig av deres endrede fysiske og psykiske helse og livsstil.

Følgende må påpekes: Vi vet ikke om de som ikke greier å slutte å røyke eller ikke har lyst til å slutte å røyke vil, etter tvungen røykeslutt, oppnå en slik reduksjon i risiko for å få lårhalsbrudd som de "frivillige" eks-røykerne oppnådde.

Hvis reversibiliteten imidlertid er så god som de foreløpige analyser kan tyde på, betyr antagelig dette at røykens effekt på remodellering av benmasse $\mathrm{i}$ hovedsak forårsaker et reversibelt bentap og i mindre grad medfører et irreversibelt bentap. Noen mener at røyking for kvinner hemmer østrogenproduksjon, som igjen medfører at remodelleringen av benmasse øker unaturlig. Osteoklastene øker sin gravevirksomhet så mye at osteoblastene ikke greier å følge riktig med det blir så mange arbeidshull i skjelettet at benmassen blir mer porøs. Når røykingen opphører, vil østrogenproduksjonen ta seg opp igjen og remodelleringen av benmasse kommer igjen på et mer naturlig nivå. Mange av arbeidshullene tettes igjen uten at nye oppstår. Det vil si, benmassen er ikke lenger så porøs. Dette er spekulasjoner. Her trengs det mer forskning.

\section{REFERANSER}

1. Forsén L, Bjørndal A, Bjartveit K, Edna T-H, Holmen J, Jessen V, Westberg G. Interaction between current smoking, leanness, and physical inactivity in the prediction of hip fracture. J Bone Miner Res 1994; 9 (11): 1671-8.

2. La Vecchia C, Negri E, Levi F, Baron JA. Cigarette smoking, body mass and other risk factors for fractures of the hip in women. Int J Epidemiol 1991; 20 (3):671-7.

3. Daniell HW. Osteoporosis of the slender smoker. Vertebral compression, fractures and loss of metacarpal cortex in relation to postmenopausal cigarette smoking and lack of obesity. Arch Intern Med 1976; 136: 298 304. 